\title{
Increased class 3 semaphorin expression modulates the invasive and adhesive properties of prostate cancer cells
}

\author{
JEFFERY G. HERMAN and GARY G. MEADOWS
}

\begin{abstract}
The Pharmacology and Toxicology Graduate Program, Department of Pharmaceutical Sciences, and the Cancer Prevention and Research Center, College of Pharmacy, Box 646713, Washington State University, Pullman, WA 99164-6713, USA
\end{abstract}

Received November 27, 2006; Accepted January 22, 2007

\begin{abstract}
The class 3 semaphorins, sema3A and sema3C, provide important guidance cues in cell development and in cancer; however, the role of these semaphorins in prostate cancer is not known. We report here that sema3 A transfected cells exhibit decreased invasion and adhesion in Matrigel-based assays and that sema3C transfected cells exhibit increased invasive and adhesive characteristics. Important adhesion proteins were differentially modulated in sema3 A and sema3C cells in a manner consistent with their subsequent invasive and adhesive characteristics. E-cadherin expression as determined by Western blot analysis was strongly upregulated in sema3A transfected cells, but strongly downregulated in sema3C transfected cells compared to untransfected and mock empty vector-transfected PC-3 cells. $\beta$-catenin levels were not changed in sema3A transfected cells; however, sema3C transfected cells had lower expression of this protein. Sema3C transfected cells exhibited greater cellular membrane expression of certain $\alpha$ integrins as compared to untransfected and sema $3 \mathrm{~A}$ transfected cells, a characteristic associated with increased adhesion and invasion. These data indicate that the invasive ability of sema3A and sema3C transfected PC-3 cells is, in part, correlated with adhesion protein expression and adhesive ability to constituents of neighboring cells and the extracellular matrix.
\end{abstract}

\section{Introduction}

Semaphorin 3A (sema3A) and semaphorin 3C (sema3C) are two members of the class 3 semaphorins, a subfamily of highly conserved proteins originally described as guidance cues for developing neurons in the central and peripheral nervous systems (1-5). Expressed in many neuronal and nonneuronal cells, semaphorins regulate numerous pathways involved in proliferation, adhesion, migration, and apoptosis (6-8). It is becoming increasingly evident that sema3 A and

Correspondence to: Dr Gary G. Meadows, Cancer Prevention and Research Center, Box 646713, Pullman, WA 99164-6713, USA E-mail: meadows@wsu.edu

Key words: semaphorin 3A, semaphorin 3C, invasion, adhesion, prostate cancer
sema3C, as well as other class 3 semaphorins play an important role in cancer; however, their role is not well-established (9-11).

Sema3A and sema3C often have opposing cellular effects, acting as either attractant or repellant guidance cues respectively during development $(8,12,13)$, and this has also been observed with certain cancers $(9,14-17)$. Sema3A decreases migration, adhesion and disrupts angiogenesis in some cancers $(14,18,19)$, while increased expression of sema3C correlates with cancers that possess higher invasive and metastatic characteristics $(7,9,16,17)$. The role of sema3 A and sema3C in androgenindependent prostate cancer has not been studied extensively and their effects in prostate cancer are not known.

Previously we found that the mRNA for sema3A, sema3C, and other class 3 semaphorins was expressed in non-malignant and malignant prostate cells, including the highly invasive androgen independent PC-3 cell lines (Herman et al, Proc Am Assoc Cancer Res 45: abs. 5081, 2004). The present study examined the novel role of sema3 A and sema3C overexpression on the invasive characteristics of the androgen-independent $\mathrm{PC}-3$ prostate cell line. We found that the regulation of invasion in response to sema3 $\mathrm{A}$ and sema3 $\mathrm{C}$ overexpression strongly correlated with the adhesive abilities of these cells. Sema3A overexpression correlated with decreased invasion and adhesion, while sema3C overexpression correlated with increased invasion and adhesion. The expression of several adhesion or adhesion-related proteins, including integrins, E-cadherin and B-catenin, were differentially modulated in cells that exhibited increased expression of sema3 $\mathrm{A}$ and sema3C, indicating an underlying mechanism by which these semaphorins can regulate invasion and adhesion.

\section{Materials and methods}

Cell culture. PC-3 prostate cancer cells were obtained from the American Type Culture Collection (Manassas, VA). PC-3 cells were cultured in RPMI-1640 (Life Technologies, Grand Island, NY) containing $10 \%$ filter sterilized fetal bovine serum [(FBS), Equitech-Bio Inc., Kerrville, TX] in a tissue culture incubator at $37^{\circ} \mathrm{C}$ in $5 \% \mathrm{CO}_{2}$ in $75-\mathrm{cm}^{2}$ tissue culture flasks (Sarstedt Inc., Newton, NC).

RT-PCR and PCR. Total RNA was extracted from cultured prostate cells using TRIzol (Invitrogen, Carlsbad, CA) (20). First-strand DNA synthesis was performed using a DT18 oligo primer custom manufactured by Invitrogen and 
Moloney murine leukemia virus (MMLV)-reverse transcriptase (Promega, Madison, WI) (20). The cDNA was amplified in a polymerase chain reaction (PCR) with gene specific primers that were based on the mRNA coding sequence of sema3 $\mathrm{A}$ and sema3C with the addition of BamHI and NotI restriction sites. The cDNA primer sequence for sema3A is 5 '-ATTGCG GCCGCATGGGCTGGT-3'/5'-TAGATGGGATCCGACAC TCCTGGGTGC-3'. The cDNA primer sequence for sema3C is 5'-CTTAGCGGCCGCATGGCATTCCGGACAA-3'/5'GATGGATCCTGACTCTGGCAACTGATTC-3'. The cDNA sequences for sema $3 \mathrm{~A}$ and sema3C were amplified by PCR. The samples were initially denatured at $95^{\circ} \mathrm{C}$ for $5 \mathrm{~min}$, followed by 40 amplification cycles. The first 10 amplification cycles consisted of a denaturation step $\left(95^{\circ} \mathrm{C}\right.$ for $\left.30 \mathrm{sec}\right)$, primer annealing $\left(60^{\circ} \mathrm{C}\right.$ and $58^{\circ} \mathrm{C}$ for sema $3 \mathrm{~A}$ and sema $3 \mathrm{C}$ respectively for $30 \mathrm{sec}$ ) and extension $\left(72^{\circ} \mathrm{C}\right.$ for $\left.2 \mathrm{~min}\right)$. The next 30 amplification cycles consisted of denaturation $\left(95^{\circ} \mathrm{C}\right.$ for $30 \mathrm{sec})$, primer annealing $\left(60^{\circ} \mathrm{C}\right.$ or $\left.58^{\circ} \mathrm{C}\right)$ and extension $\left(72^{\circ} \mathrm{C}\right.$ for $2 \mathrm{~min}$ ), and increased by $10 \mathrm{sec}$ with each subsequent cycle. The 40 amplification cycles were followed by a final extension period of $10 \mathrm{~min}$ at $72^{\circ} \mathrm{C}$ to ensure full extension and proper amplification of the sema $3 \mathrm{~A}$ and sema3C cDNA products. The cDNA products were electrophoresed onto a $2.2 \%$ agarose gel containing ethidium bromide using a $150 \mathrm{~V}$ current and visualized under ultraviolet light. Hypoxyanthineguanine phosphoribosyltransferase (HPRT, 5'-GAGAGTTC AAGTTGAGTTTG-3'/5'-TTTTCTAACACACGGTGGTA-3') was used as an internal control.

Ligation and transfection. Ligation and transfection were performed as described previously (21). The amplified sema3A and sema3C PCR products were cleaved using NotI and BamHI restriction enzymes obtained from Promega and ligated into the pCMV-Tag1 vector from Stratagene (La Jolla, CA) according to the manufacturer's specifications. The pCMVTag1 vector contains a kanamycin and G418 resistance gene for transfection of bacteria and mammalian cells respectively. The vectors containing sema3 A and sema3C were transfected into competent XL1-Blue bacteria from Stratagene (22). The bacterial clones transfected with sema3A or sema3C were grown on agar plates and selected with $35 \mu \mathrm{g} / \mathrm{ml}$ of kanamycin (23). PCR was then used to confirm the presence of the specific semaphorin genes. The vector with the gene of interest was purified using the Concert Nucleic Acid Purification system from Marligen (Ijamsville, MD). The gene/vector was then transfected into PC-3 cells using the Transit Prostate Transfection Reagent (Mirus Bio Corporation, Madison, WI). Stably transfected cells were selected with $0.5 \mu \mathrm{g} / \mathrm{ml} \mathrm{G} 418$ (Invitrogen) (24). As a control for transfection, a mock empty vector (mEV), pCMV-Tag1 vector from Stratagene without any inserted PCR product was transfected into the cells and similarly selected.

RNA slot blot analysis. Briefly, cultured PC-3 cells were harvested from tissue culture dishes using scrapers after washing the cell monolayers with $0.1 \%$ diethylpyrocarbonate (DEPC)-treated phosphate-buffered solution (PBS, $137 \mathrm{mM}$ $\mathrm{NaCl}, 2.7 \mathrm{mM} \mathrm{KCl}, 4.3 \mathrm{mM} \mathrm{Na} \mathrm{HPO}_{4}, 1.47 \mathrm{mM} \mathrm{KH}_{2} \mathrm{PO}_{4}$ ) (21). Cells were transferred to a 50-ml tube and centrifuged at $2000 \mathrm{rpm}(600 \mathrm{x} \mathrm{g})$. mRNA was extracted and purified using the Invitrogen Micro-FasTrack 2.0 system according to the manufacturer's specifications. mRNA was used in an RT-PCR and subsequent PCR with biotin-labeled CTP to create gene-specific probes to confirm semaphorin expression by slot blot analysis as previously described (25). Briefly the total RNA extracted from the above cells was transferred onto a nylon membrane (Osmonics Inc., Minnetonka, MN) using a slot blot manifold apparatus. The RNA was linked and stabilized to the membrane using a UV-Stratalinker 1800 (Stratagene). The membrane was hybridized with an appropriate cell specific cDNA probe and detected with alkaline-phosphatase streptavidin and CDP-Star from Kirkegaard \& Perry Laboratories Inc. (Gaithersburg, MD). The RNA was visualized via X-ray film. Differences in density of sema3A and sema3C RNA were determined in untransfected cells, semaphorin transfectants, and mEV cells as compared to HPRT used as an internal control (Herman et al, Proc Am Assoc Cancer Res 44: abs. 2674, 2003).

Growth and viability assay. Untransfected PC-3 cells and sema3A-, sema3C-, and mEV-transfected PC-3 cells were plated in $60 \times 15-\mathrm{mm}$ tissue culture dishes at a concentration of $2 \times 10^{5}$ cells and growth was measured over a span of four days (26). Cells were trypsinized, collected, and counted using the Vi-Cell XR cell counter (Beckman Coulter, Fullerton, CA). Cell viability was determined by the cell counter using trypan blue exclusion (27). Cell counts and cell viability determinants were performed in triplicate for each time-point, and the experiments were repeated twice with similar results.

Chemoinvasion assay. The invasion assay was performed as described previously using a microinvasion chamber $(28,29)$. Briefly, cells were collected at 50-70\% confluency. Cells $(100,000)$ were incubated in the upper wells suspended in serum-free media with $0.1 \%$ bovine serum albumin (BSA). The lower wells contained complete growth media with $10 \%$ FBS, which was used as a chemoattractant to facilitate invasion. An 8- $\mu \mathrm{m}$ porous Nucleopore Track Etch Membrane (Whatman, Alameda, CA) was coated with $50 \mu \mathrm{g} / \mathrm{ml}$ of Matrigel (BD Biosciences, Bedford, MA), separating the upper and lower wells $(28,29)$. PC-3 cells were incubated for $20 \mathrm{~h}$ at $37^{\circ} \mathrm{C}$ in the tissue culture incubator. Cells that invaded through the Matrigel to the underside of the membrane were counted using a light microscope after being fixed in methanol and stained with Diff-Quik (Dade Behring Inc., Deerfield, IL). Approximately six optical fields were counted per well at magnification $x 400$. Experiments were repeated four to five times and the results were averaged. The results were presented as the percentage of invasion of the semaphorin transfected cells compared to untransfected PC-3 cells \pm SEM.

Adhesion assay. Adhesion of PC-3 cells was measured as previously described with some modifications $(28,30)$. Each well of a $24-w e l l$ plate was coated with $100 \mu \mathrm{g} / \mathrm{ml}$ of Matrigel. In each well, $2 \times 10^{4}$ cells were added in $0.5 \mathrm{ml}$ serum-free media supplemented with $0.1 \%$ BSA. The plates were incubated at $37^{\circ} \mathrm{C}$ and adhesion was determined at 20,30, 45, and $60 \mathrm{~min}$. The plates were fixed with methanol, stained with DiffQuik and washed with PBS. Adhesion of cells to Matrigel was counted in five random fields per well in duplicate at 


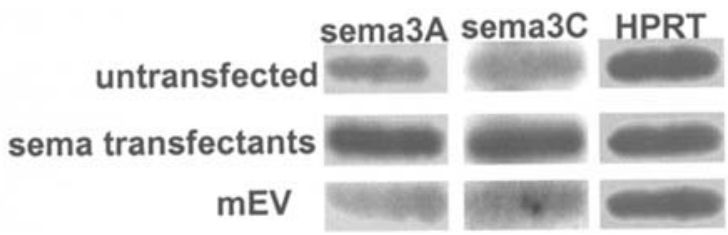

Figure 1. Sema3A and sema3C overexpression in PC-3 cells measured by RNA slot blot analysis. PC-3 cells cultured in RPMI-1640 + 10\% FBS were harvested at 50-70\% confluence. Total RNA was extracted from semaphorin transfected, $\mathrm{mEV}$, and untransfected cells using TRIzol and was transferred to a nitrocellulose membrane using an RNA slot blot manifold. The RNA samples were stabilized by ultraviolet light. The membrane was hybridized with biotin linked with cell specific PCR probe, and HPRT was used as a loading control.

magnification $\mathrm{x} 400$, and the results were averaged. The experiments were repeated twice. All transfected cells were compared to untransfected PC-3 cells.

Western blot analysis. E-cadherin and B-catenin levels were determined by Western blot analysis as previously described (28). Briefly, attached PC-3 cells were washed with PBS and collected by scraping. The cells were transferred to a $50 \mathrm{ml}$ conical tube and centrifuged at $2000 \mathrm{rpm}(600 \mathrm{x} \mathrm{g})$ for $10 \mathrm{~min}$. The cell pellet was collected and lysed with an ice cold buffer (100 mM NaCl, 10 mM Tris-HCl, pH 7.4, 1\% Triton X-100, $0.1 \%$ SDS, $0.5 \%$ deoxycholate, $10 \%$ glycerol) supplemented with $10 \mu 1$ of Protease Inhibitor Cocktail, $10 \mu 1$ Phosphatase Inhibitor Cocktail I and $10 \mu 1$ Phosphatase Inhibitor Cocktail II all from Sigma (St. Louis, MO). The lysate was centrifuged at $8765 \mathrm{x}$ g for $10 \mathrm{~min}$. The supernatant was collected and the protein concentration was determined using the Bradford assay (Bio-Rad Laboratories, Hercules, CA) as described by the manufacturer. Equal amounts of protein lysate were added to a denaturing loading dye (125 mM Tris-HCl, 4\% SDS, $20 \%$ glycerol, $10 \%$ 2-mercaptoethanol, $0.004 \%$ bromphenol blue) and boiled for $5 \mathrm{~min}$. The samples were separated by 4-10\% SDS gradient PAGE gel electrophoresis and electrotransferred to a nitrocellulose membrane (Osmonics Inc.). The nitrocellulose membrane was immunoblotted with polyclonal antibodies against E-cadherin and $\beta$-catenin obtained from Cell Signaling Technology (Danvers, MA). Membranes were also immunoblotted with anti-glyceraldehyde 3-phosphate (GAPDH) obtained from Abcam (Cambridge, MA). GAPDH was used as an internal loading control. The relative amount of protein in semaphorin transfectants was expressed as a percentage of untransfected cells.

Integrin expression. Cell surface integrin expression was measured by flow cytometry as described previously (31). Sema3A and sema3C transfected PC-3 cells and untransfected cells were collected and suspended in PBS supplemented with $0.1 \%$ sodium azide and stained with fluorescein isothiocyanate (FITC)-or phycoerythrin (PE)-labeled monoclonal antibodies against the following human integrin subunits: $\alpha 1, \alpha 2, \alpha 3, \alpha 4$, $\alpha 5, \alpha 6, \alpha v, \beta 2$, and 33 (BD Pharmingen, San Diego, CA). Ten thousand events were analyzed by flow cytometry on a FACScan (BD Biosciences) for each sample. FITC- and PElabeled IgG1 were used to identify nonspecific background staining.

Statistical analyses. Statistical analysis of invasion was determined using One-way ANOVA followed by Bonferroni's multicomparison test. Statistical analysis of adhesion was determined using a two-way ANOVA followed by Bonferroni's multicomparison test. Statistics were performed using GraphPad Prism version 4.0 software (San Diego, CA). Values were considered significant at $\mathrm{P} \leq 0.001$.

\section{Results}

Transfection and growth assay. Fig. 1 shows that the sema3A and sema3C stably transfected PC-3 cells express a 2-fold increase in mRNA compared to untransfected cells. The mock mEV control vector transfected into PC-3 cells did not show any difference in semaphorin expression compared to untransfected cells (Fig. 1). We were unable to determine protein expression by Western blot analysis of the two semaphorins in the transfected cells using available commercial antibodies.
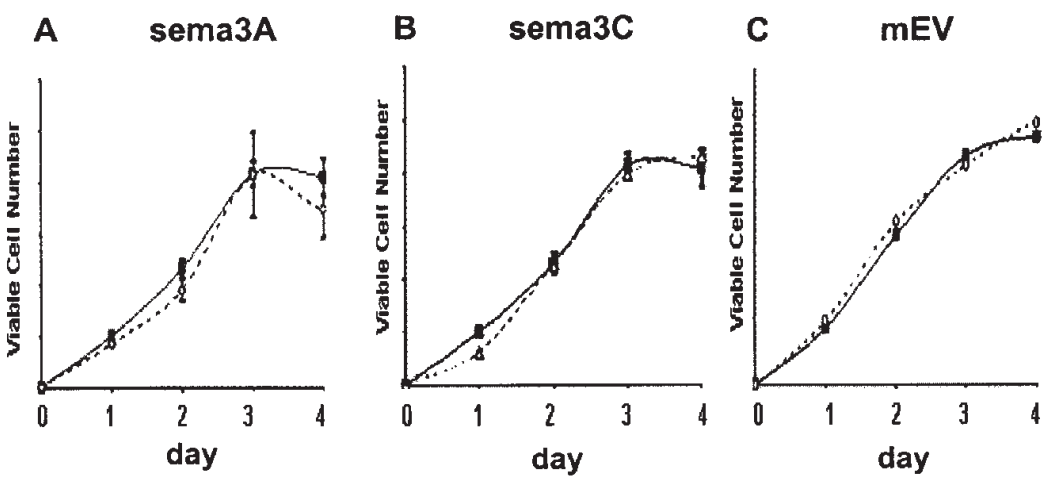

Figure 2. Effect of sema3A, sema3C, and mEV transfection on cell growth. Cells were cultured in RPMI-1640 + 10\% FBS. Semaphorin and mEV transfected cells were further cultured in medium containing $0.5 \mathrm{mg} / \mathrm{ml}$ of G418. Cells were plated at a seeding density of $2.5 \times 10^{5}$ in $60 \times 15$-mm tissue culture dishes. Three separate dishes were utilized for each cell line and time-point. At the indicated times the cell monolayers of each dish were trypsinized, the cells washed with PBS, and then counted with a Vi-Cell XR cell counter. Cell counts were collected daily for 4 days. Fifty counts per sample were analyzed by the cell counter and averaged for each time-point, and this was performed in triplicate for each group. The experiments were performed twice and the graphs represent the mean \pm SEM of the two growth assays. A, sema3A; B, sema3C; and C, mEV, all compared to untransfected PC-3 cells. Transfectants are represented by a dashed line and open shapes, and untransfected cells are represented by the black line with solid shapes. 


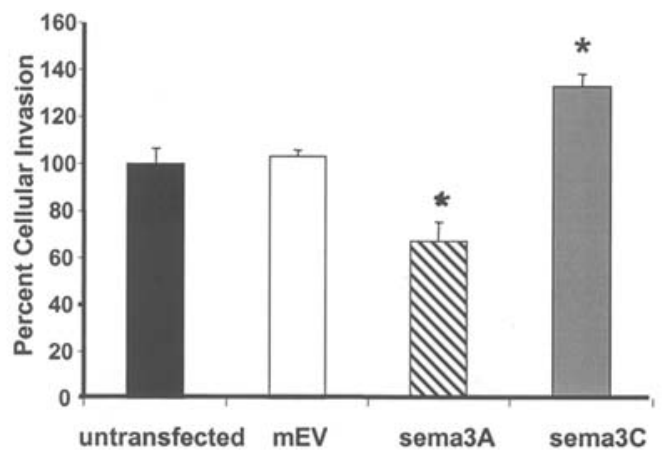

Figure 3. Sema3A and sema3C upregulation differentially modulate invasion of PC-3 cells. The invasion assay was performed as described previously (28). Cells were grown in RPMI-1640 + 10\% FBS and harvested at 50-70\% confluence. They were then resuspended in $50 \mu 1$ serum-free cell medium supplemented with $0.1 \%$ BSA and seeded into the upper wells of a microinvasion chamber, separated from the lower wells containing FBS by an $8-\mu \mathrm{m}$ porous membrane coated with $50 \mu \mathrm{g} / \mathrm{ml}$ Matrigel. Cells invading to the underside of the membrane were stained with Diff-Quik and counted. Six random fields were counted and the results were averaged. The mean \pm SEM from three separate experiments are presented as a percentage of cellular invasion of semaphorin transfectants compared to untransfected controls. Invasion of untransfected cells was set at a baseline level of $100 \%$. $^{*}$ Different from untransfected cells at $\mathrm{P} \leq 0.001$. Black bar, untransfected cells; white bar, $\mathrm{mEV}$; hatched bar, sema3A transfected cells; and gray bar, sema3C transfected cells.

The growth rates of stable semaphorin and mEV transfectants were comparable to the growth rate of untransfected cells (Fig. 2). Cellular viability of the transfected cells was $\sim 95 \%$ and did not show any significant differences compared to untransfected cells. These data indicate that neither semaphorin transfection nor semaphorin overexpression significantly affect PC-3 cell growth or viability.

Overexpression of sema3A decreases and overexpression of sema $3 C$ increases the invasive and adhesive characteristics of $P C-3$ cells. Transfection of sema3A and sema3C altered the invasive characteristics of PC-3 cells (Fig. 3). Overexpression of sema3 A in PC-3 decreased the invasive characteristics of PC-3 cells by $33 \%$ compared to the untransfected cells. Sema3C, on the other hand, increased invasion by $33 \%$ compared to untransfected cells. Invasion of mEV cells was not significantly different from untransfected cells.

Interaction of cancer cells with various key components of the extracellular matrix (ECM) and neighboring cells is a vital regulator of invasion (32-34). The regulation of invasion in response to semaphorin expression strongly correlated with adhesion. Adhesion of PC-3 cells to Matrigel was measured at time-points between 20-60 min. Cellular adhesion did not differ at any of the time-points. Sema3A overexpressed PC-3 cells exhibited decreased adhesion to Matrigel by $\sim 23 \%$ at 30 min, while adhesion was increased in sema3C transfected cells by $20 \%$ at $30 \mathrm{~min}$ (Fig. 4).

E-cadherin and $\beta$-catenin expression are differentially regulated in sema $3 A$ and sema $3 C$ overexpressing $P C-3$ cells. To understand the underlying mechanism by which semaphorins regulate invasion and adhesion of PC-3 cells, we measured the expression of E-cadherin and $\beta$-catenin in sema3A and sema3C transfected cells. E-cadherin and B-catenin

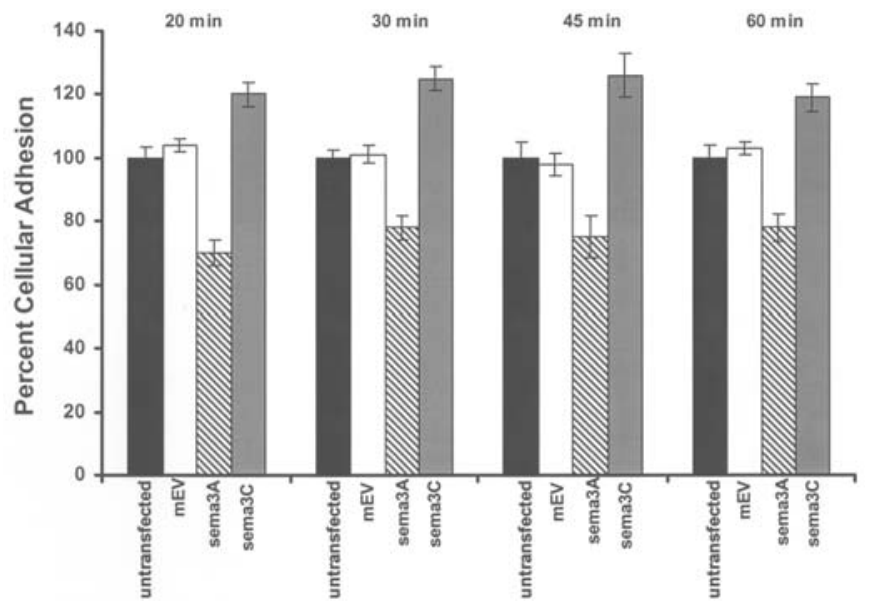

Figure 4. Effect of sema3A and sema3C overexpression on the adhesive characteristics of PC-3 cells. Each well of a 24-well plate was coated with $100 \mu \mathrm{g}$ of Matrigel. Twenty thousand cultured cells were resuspended in $500 \mu 1$ of RPMI- $1640+0.1 \%$ BSA per well. Adherent cells were counted at $20,30,45$ and $60 \mathrm{~min}$. For each time-point, five random fields were counted in two separate wells and the results were averaged. The experiments were repeated twice. The mean \pm SEM from the two experiments is presented as a percent of cellular adhesion compared to untransfected cells. Adhesion of untransfected cells was set at a baseline level of $100 \%$. *Different from untransfected cells at $\mathrm{P} \leq 0.001$. Black bar, untransfected cells; white bar, $\mathrm{mEV}$; hatched bar, sema3 A transfected cells; and gray bar, sema3C transfected cells.

A

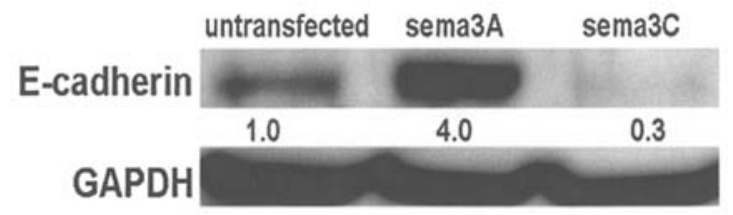

B

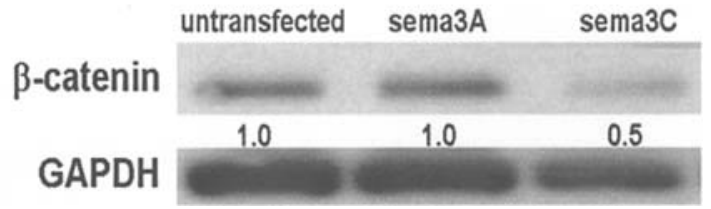

Figure 5. E-cadherin and $B$-catenin regulation in sema3 $\mathrm{A}$ and sema3C transfected PC-3 cells. Cellular protein lysates from untransfected and sema3A and sema3C transfected PC-3 cells were collected, separated by $10 \%$ SDS PAGE electrophoresis, transferred to a nitrocellulose membrane, and expression was determined by Western blot analysis. A, total E-cadherin; B, B-catenin. GAPDH protein expression was used as an internal control. The numbers represent the relative density of protein expression in semaphorin transfected cells normalized to GAPDH compared to normalized protein expression in untransfected cells.

are two important adhesion proteins that function together to form an important transmembrane cell-cell adhesion complex with important anti-invasive properties in prostate cancer (35-39). E-cadherin expression was upregulated 4-fold in PC-3 cells overexpressing sema3A compared to untransfected controls (Fig. 5A); however, $\beta$-catenin levels were not altered (Fig. 5B). Sema3C transfected PC-3 cells exhibited a $>3$-fold 

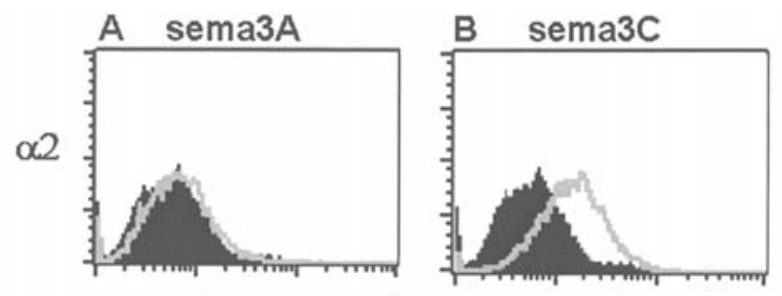

$\alpha 3$
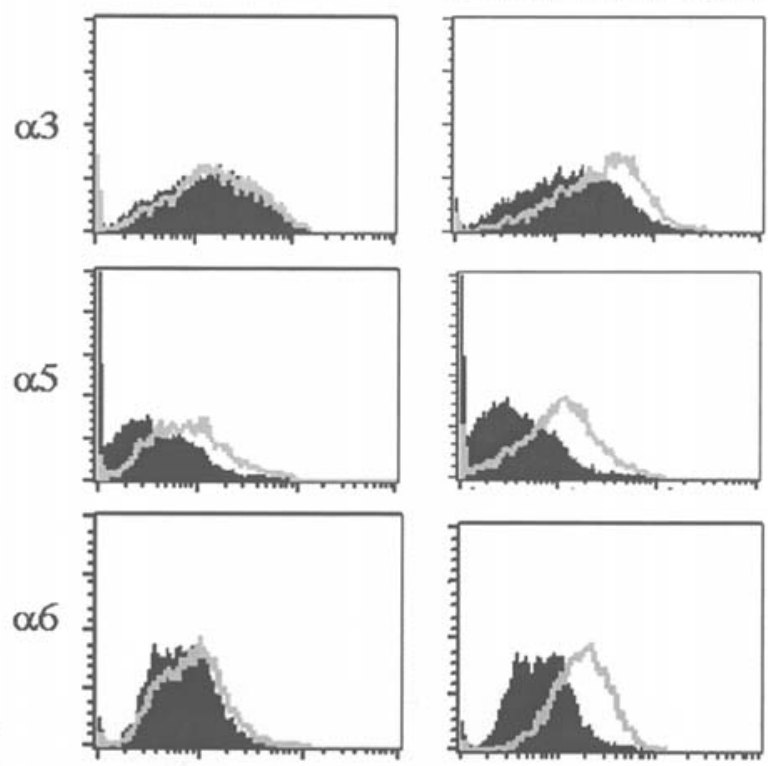

Figure 6. Differential integrin expression in sema3A and sema3C transfected PC-3 cells. Integrin expression was determined in untransfected and in sema3 A and sema3C transfected PC-3 cells by flow cytometry using fluorescein isothiocyanate (FITC)-labeled or phycoerythrin (PE)-labeled monoclonal mouse antibodies raised against human integrin proteins, $\alpha 2$, $\alpha 3, \alpha 5$, and $\alpha 6$. A, sema $3 \mathrm{~A}$; and $\mathrm{B}$, sema3C expression compared to untransfected PC-3 cells. The filled black histograms represent untransfected cells and the gray line represents respective sema3 A and sema3C transfected cells.

decrease in E-cadherin expression (Fig. 5A) and a 2-fold decrease in $\beta$-catenin levels (Fig. 5B).

Differential integrin expression in sema3A and sema3C overexpressing $P C-3$ cells. Integrins are essential transmembrane proteins that mediate cellular adhesion to the ECM and are often deregulated in cancer, leading to changes in invasion and metastasis $(40,41)$. Untransfected or transfected PC-3 cells did not express $\alpha 1, \alpha 4, \alpha v, \beta 2$, or $\beta 3$ integrins on their surface. Cells overexpressing sema3A exhibited an increased surface expression of the $\alpha 5$ integrin, but did not show any difference in expression of $\alpha 2, \alpha 3$, or $\alpha 6$ integrins (Fig. 6A). Membrane integrin levels were expressed differently in sema3C transfected cells as compared to sema3A transfected cells. These cells exhibited increased expression of $\alpha 2, \alpha 3, \alpha 5$, and $\alpha 6$ integrins (Fig. 6B).

\section{Discussion}

Prostate cancer is a severe epidemic and one of the fastest rising neoplasms in the United States. It is a leading cause of cancerrelated deaths in men, second only to that of lung cancer (42). Prostate cancer is a very slow growing disease; however, malignant prostate cells often invade and metastasize to various organ systems, including the lung, bone and brain, severely increasing patient mortality $(32,43-46)$.

Previously, we found that several semaphorins, including sema3 A and sema3C were expressed in cultured malignant as well as non-malignant prostate cells. During development, sema3A and sema3C, two conserved members of the vertebrate class 3 semaphorin family, often act in an opposing fashion as a chemorepellant or chemoattractant, respectively $(6,8,12)$. This signaling dichotomy of attraction and repulsion in response to sema3 A and sema3C in conjunction with other guidance proteins is essential for the proper development of various organ systems $(6,8,12)$. Sema3A and sema3C also have opposing roles in cancer $(7,9,16,17)$.

The role of sema3 $\mathrm{A}$ and sema3 $\mathrm{C}$ in invasion has not been studied extensively. Focusing on the highly invasive androgenindependent PC-3 prostate cancer cell line, we show that sema $3 \mathrm{~A}$ and sema $3 \mathrm{C}$ regulate invasion and adhesion in an opposing fashion. Sema3A transfected PC-3 cells exhibit decreased invasive and adhesive characteristics compared to untransfected and mEV cells, while sema3C transfected cells exhibited increased invasion and decreased adhesion compared to the same control cells. These data are consistent with other reports indicating that sema3 A upregulation decreases adhesion of endothelial cells (47) and that increased sema3A expression inhibits breast cancer migration (48). In addition, increased expression of sema3C is correlated with increased lung cancer metastasis (7) and decreased survivability of patients with breast or ovarian cancer (17).

In preliminary studies, we observed that invasion of another androgen-independent prostate cancer cell line, DU145, was similarly modulated by sema $3 \mathrm{~A}$ and sema $3 \mathrm{c}$ transfection as compared to PC-3 cells (not shown). Transfection of non-invasive, androgen-dependent LNCaP prostate cells with sema3 A and sema3C did not alter the invasive characteristics of these cells (not shown). These findings indicate that androgendependent and -independent prostate cancer cells respond differently to upregulation of sema3A and sema3C. This could suggest that the functional androgen receptor is involved in the regulation of sema3 $\mathrm{A}$ and sema $3 \mathrm{C}$ signaling in androgendependent prostate cancer. Although it is known that expression of neuropilin, a receptor for class 3 semaphorins, is upregulated by progesterone (49), a connection between hormones, the androgen receptor, and semaphorins has never been studied among the different prostate cancer cell lines.

Changes in invasion often correlate with differences in regulation of important cell-cell and cell-ECM adhesion proteins $(40,41)$. Cell-cell and cell-matrix proteins are necessary for the proper maintenance of tissue integrity $(40,41)$. These adhesion proteins also have important roles in wound healing; however, if they become deregulated, this can lead to increased malignancy $(40,41)$. In this study we showed that semaphorin transfected cells differentially express important cell-cell (E-cadherin/ß-catenin) and cell-ECM (integrin) proteins. The differences in these cell adhesion proteins between the sema3A and sema3C transfected PC-3 cells strongly correlate with their subsequent invasive and adhesive characteristics. E-cadherin expression is upregulated 4-fold in sema3Atransfected PC-3 cells, although 3 -catenin levels are not changed compared to untransfected cells. Upregulation of E-cadherin is correlated with decreased invasion of PC-3 
cells (37-39). In contrast, sema3C transfected cells exhibited a strong downregulation of E-cadherin and B-catenin proteins as compared to untransfected cells. Decreased E-cadherin levels are thought to be a prognostic factor in the progression of malignant cancers to an increased metastatic stage $(37,50)$. E-cadherin expression is also lower in the highly invasive PC-3 cells compared to normal cells $(37,51)$.

While E-cadherin and $B$-catenin are important in the regulation of invasion and adhesion of sema3 $\mathrm{A}$ and sema3C transfected PC-3 cells, integrins, an important class of cellECM adhesion proteins, also play a role. Integrin expression and activity is deregulated in PC-3 cells, other forms of prostate cancer, and various other types of neoplastic tissue, leading to aberrant adhesion and invasion (52-55). The level of integrin expression is relatively unchanged in sema3 A transfected cells except for an increase in $\alpha 5$ levels compared to untransfected cells. Sema3C also exhibit a similar increase in $\alpha 5$ levels. The exact role that $\alpha 5$ integrin has in semaphorin signaling and prostate cancer invasion is unclear. It is reported that DU145 cells transfected with the androgen receptor exhibit increased surface expression of $\alpha 5$ integrin, and that this correlates with decreased invasion across a Matrigel-coated membrane (56). Although these data might only be pertinent to the androgen receptor-transfected DU145 cells, they could indicate a possible mechanism by which sema3A transfected cells exhibit lower invasive and adhesive properties. However, increased surface expression of $\alpha 5$ integrin alone does not explain the increased invasion and adhesion that is observed in sema3C transfected cells.

In addition to increased cell surface expression of $\alpha 5$ integrin, sema3C transfected cells showed a marked increase in cell surface expression of $\alpha 2, \alpha 3$, and $\alpha 6$ integrins, and this pattern is consistent with increased invasion of PC-3 cells. Increased expression of these integrins is correlated with increased adhesion, invasion and metastasis (53,57-60). Increased $\alpha 2$ and $\alpha 3$ expression correlates with increased adhesion of PC-3 cells (61-64). Increased $\alpha 3$ and $\alpha 6$ integrin expression is also indicative of increased invasion and more aggressive prostate tumors $(60,65,66)$. Since sema3C transfected cells exhibit increased expression of $\alpha 2, \alpha 3$ and $\alpha 6$, three integrins that correlate with increased malignancy and invasion, this could overshadow the anti-invasive effects of $\alpha 5$ integrin increased expression (53).

The increased surface expression of $\alpha 2$ and $\alpha 3$ integrins in sema3C transfected cells correlates strongly with decreased expression of E-cadherin. It was recently found that downregulation of E-cadherin leads to a significant increase in $\alpha 2$ and $\alpha 3$ integrin levels in a squamous cell carcinoma (67). In these cells, changes in integrin expression and E-cadherin expression mediate increased invasion (67). These data suggest that sema3C upregulation in PC-3 cells could regulate invasion and adhesion through crosstalk between cell-cell and cell-ECM adhesion pathways.

In this study we showed a novel regulation of sema3 $\mathrm{A}$ and sema3C on prostate cancer invasion. We found a strong association between cell-cell (E-cadherin/ß-catenin) and cellECM (integrin) adhesion proteins and invasion of sema3 $\mathrm{A}$ and sema3C transfected PC-3 cells. These cells display opposing characteristics with sema3 A transfected cells exhibiting decreased invasion and adhesion and sema3C transfected cells exhibiting increased invasion and adhesion. With additional understanding of their ability to regulate invasion, targeting specific semaphorin proteins could lead to the development of new anti-cancer therapies.

\section{Acknowledgements}

This study was supported in part by a grant from the National Institutes of Health, CA101035.

\section{References}

1. Castellani V and Rougon G: Control of semaphorin signaling. Curr Opin Neurobiol 12: 532-541, 2002.

2. $\mathrm{Yu} \mathrm{HH}$ and Kolodkin AL: Semaphorin signaling: a little less per-plexin. Neuron 22: 11-14, 1999.

3. Brown CB, Feiner L, Lu MM, Li J, Ma X, Webber AL, Jia L, Raper JA and Epstein JA: PlexinA2 and semaphorin signaling during cardiac neural crest development. Development 128: 3071-3080, 2001.

4. Cohen S, Funkelstein L, Livet J, Rougon G, Henderson CE, Castellani V and Mann F: A semaphorin code defines subpopulations of spinal motor neurons during mouse development. Eur J Neurosci 21: 1767-1776, 2005.

5. Gu C, Rodriguez ER, Reimert DV, Shu T, Fritzsch B, Richards LJ, Kolodkin AL and Ginty DD: Neuropilin-1 conveys semaphorin and VEGF signaling during neural and cardiovascular development. Dev Cell 5: 45-57, 2003.

6. Lepelletier Y, Moura IC, Hadj-Slimane R, Renand A, Fiorentino S, Baude C, Shirvan A, Barzilai A and Hermine O: Immunosuppressive role of semaphorin-3A on $\mathrm{T}$ cell proliferation is mediated by inhibition of actin cytoskeleton reorganization. Eur J Immunol 7: 1782-1793, 2006.

7. Bagnard D, Vaillant C, Khuth ST, Lohrum M, Puschel AW, Belin MF, Bolz J and Thomasset N: Semaphorin 3A-vascular endothelial growth factor-165 balance mediates migration and apoptosis of neural progenitor cells by the recruitment of shared receptor. J Neurosci 21: 3332-3341, 2001.

8. Goshima Y, Ito T, Sasaki Y and Nakamura F: Semaphorins as signals for cell repulsion and invasion. J Clin Invest 109: 993-998, 2002.

9. Neufeld G, Shraga-Heled N, Lange T, Guttmann-Raviv N, Herzog Y and Kessler O: Semaphorins in cancer. Front Biosci 10: 751-760, 2005.

10. Chedotal A, Kerjan G and Moreau-Fauvarque C: The brain within the tumor: new roles for axon guidance molecules in cancers. Cell Death Differ 12: 1044-1056, 2005.

11. Klagsbrun M and Eichmann A: A role for axon guidance receptors and ligands in blood vessel development and tumor angiogenesis. Cytokine Growth Factor Rev 16: 535-548, 2005.

12. Rieger J, Wick W and Weller M: Human malignant glioma cells express semaphorins and their receptors, neuropilins and plexins. Glia 42: 379-389, 2003

13. Bagnard D, Thomasset N, Lohrum M, Puschel AW and Bolz J: Spatial distributions of guidance molecules regulate chemorepulsion and chemoattraction of growth cones. J Neurosci 20: 1030-1035, 2000.

14. Yasuhara T, Shingo T, Kobayashi K, Takeuchi A, Yano A, Muraoka K, Matsui T, Miyoshi Y, Hamada H and Date I: Neuroprotective effects of vascular endothelial growth factor (VEGF) upon dopaminergic neurons in a rat model of Parkinson's disease. Eur J Neurosci 19: 1494-1504, 2004.

15. Catalano A, Caprari P, Rodilossi S, Betta P, Castellucci M, Casazza A, Tamagnone L and Procopio A: Cross-talk between vascular endothelial growth factor and semaphorin-3A pathway in the regulation of normal and malignant mesothelial cell proliferation. FASEB J 18: 358-360, 2004.

16. Martin-Satue M and Blanco J: Identification of semaphorin E gene expression in metastatic human lung adenocarcinoma cells by mRNA differential display. J Surg Oncol 72: 18-23, 1999.

17. Galani E, Sgouros J, Petropoulou C, Janinis J, Aravantinos G, Dionysiou-Asteriou D, Skarlos D and Gonos E: Correlation of MDR-1, nm23-H1 and H Sema E gene expression with histopathological findings and clinical outcome in ovarian and breast cancer patients. Anticancer Res 22: 2275-2280, 2002 . 
18. Klagsbrun M, Takashima S and Mamluk R: The role of neuropilin in vascular and tumor biology. Adv Exp Med Biol 515: 33-48, 2002.

19. Schwarz Q, Gu C, Fujisawa H, Sabelko K, Gertsenstein M, Nagy A, Taniguchi M, Kolodkin AL, Ginty DD, Shima DT and Ruhrberg C: Vascular endothelial growth factor controls neuronal migration and cooperates with Sema3A to pattern distinct compartments of the facial nerve. Genes Dev 18: 2822-2834, 2004.

20. Meadows GG, Zhang $\mathrm{H}$ and Ge X: Specific amino acid deficiency alters the expression of genes in human melanoma and other tumor cell lines. J Nutr 131: S3047-S3050, 2001.

21. Sambrook J, Fritsch EF and Maniatis T: Molecular Cloning: A Laboratory Manual. Cold Spring Harbor Press, Cold Spring Harbor, New York, 1989.

22. Hanahan D: Studies on transformation of Escherichia coli with plasmids. J Mol Biol 166: 557-580, 1983.

23. Joshi BH and Puri RK: Optimization of expression and purification of two biologically active chimeric fusion proteins that consist of human interleukin-13 and Pseudomonas exotoxin in Escherichia coli. Protein Expr Purif 39: 189-198, 2005.

24. Yang DZ, He J, Zhang JC and Wang ZR: Angiostatin inhibits pancreatic cancer cell proliferation and growth in nude mice. World J Gastroenterol 11: 4992-4996, 2005.

25. Bown T, Mackey $\mathrm{K}$ and Tingting D: Current Protocols in Molecular Biology. John Wiley \& Sons, Inc., New York, 2004.

26. Bunyaratavej P, Hullinger TG and Somerman MJ: Bone morphogenetic proteins secreted by breast cancer cells upregulate bone sialoprotein expression in preosteoblast cells. Exp Cell Res 260: 324-333, 2000.

27. Handayani R, Rice L, Cui Y, Medrano TA, Samedi VG, Baker HV, Szabo NJ and Shiverick KT: Soy isoflavones alter expression of genes associated with cancer progression, including interleukin-8, in androgen-independent PC-3 human prostate cancer cells. J Nutr 136: 75-82, 2006.

28. Pelayo BA, Fu Y-M and Meadows GG: Decreased tissue plasminogen activator and increased plasminogen activator inhibitors are associated with inhibition of invasion in human A375 melanoma deprived of tyrosine and phenylalanine. Int J Oncol 18: 877-883, 2001

29. Hendrix MJC, Seftor EA, Seftor REB and Fidler IJ: A simple quantitative assay for studying the invasive potential of high and low human metastatic variants. Cancer Lett 38: 137-147, 1987.

30. Uhlenkott CE, Huijzer JC, Cardeiro DJ, Elstad CA and Meadows GG: Attachment, invasion, chemotaxis and proteinase expression of B16-BL6 melanoma cells exhibiting a low metastatic phenotype after exposure to dietary restriction of tyrosine and phenylalanine. Clin Exp Metastasis 14: 125-137, 1996.

31. Fu Y-M, Zhang H, Ding M, Li Y-Q, Fu X, Yu Z and Meadows GG: Specific amino acid restriction inhibits attachment and spreading of human melanoma via modulation of the integrin/focal adhesion kinase pathway and actin cytoskeleton remodeling. Clin Exp Metastasis 21: 587-598, 2004.

32. Tantivejkul K, Kalikin LM and Pienta KJ: Dynamic process of prostate cancer metastasis to bone. J Cell Biochem 91: 706-717, 2004.

33. Peehl DM: Primary cell cultures as models of prostate cancer development. Endocr Relat Cancer 12: 19-47, 2005.

34. Edward M and MacKie RM: Cell-cell and cell-extracellular matrix interactions during melanoma cell invasion and metastasis. Melanoma Res 3: 227-234, 1993.

35. Jaggi M, Johansson SL, Baker JJ, Smith LM, Galich A and Balaji KC: Aberrant expression of E-cadherin and betacatenin in human prostate cancer. Urol Oncol 23: 402-406, 2005 .

36. Harrington $\mathrm{KJ}$ and Syrigos $\mathrm{KN}$ : The role of E-cadherin-catenin complex: more than an intercellular glue? Ann Surg Oncol 7: 783-788, 2000.

37. Chu Q, Ling MT, Feng H, Cheung HW, Tsao SW, Wang X and Wong YC: A novel anticancer effect of garlic derivatives: inhibition of cancer cell invasion through restoration of E-cadherin expression. Carcinogenesis 27: 2180-2189, 2006.

38. Furbert-Harris PM, Parish-Gause D, Hunter KA, Vaughn TR, Howland C, Okomo-Awich J, Forrest K, Laniyan I, Abdelnaby A and Oredipe OA: Activated eosinophils upregulate the metastasis suppressor molecule E-cadherin on prostate tumor cells. Cell Mol Biol 49: 1009-1016, 2003.
39. Campbell MJ, Elstner E, Holden S, Uskokovic M and Koeffler HP: Inhibition of proliferation of prostate cancer cells by a 19-nor-hexafluoride vitamin D3 analogue involves the induction of p21waf1, p27kip1 and E-cadherin. J Mol Endocrinol 19: 15-27, 1997.

40. Foty RA and Steinberg MS: Cadherin-mediated cell-cell adhesion and tissue segregation in relation to malignancy. Int J Dev Biol 48: 397-409, 2004.

41. Hinz B and Gabbiani G: Cell-matrix and cell-cell contacts of myofibroblasts: role in connective tissue remodeling. Thromb Haemost 90: 993-1002, 2003.

42. Mazhar D WJ: Prostate cancer. Postgrad Med J 924: 590-595, 2002.

43. Cooper CR PKJ: Cell adhesion and chemotaxis in prostate cancer metastasis to bone: a mini review. Prostate Cancer Prostatic Dis 3: 6-12, 2000.

44. Rubio N, Villacampa MM, El Hilali N and Blanco J: Metastatic burden in nude mice organs measured using prostate tumor PC-3 cells expressing the luciferase gene as a quantifiable tumor cell marker. Prostate 44: 133-143, 2000.

45. Benjamin R: Neurologic complications of prostate cancer. Am Fam Physician 65: 1834-1840, 2002.

46. Thalmann GN, Sikes RA, Wu TT, Degeorges A, Chang SM, Ozen M, Pathak S and Chung LW: LNCaP progression model of human prostate cancer: androgen-independence and osseous metastasis. Prostate 44: 91-103, 2000.

47. Serini G, Valdembri D, Zanivan S, Morterra G, Burkhardt C, Caccavari F, Zammataro L, Primo L, Tamagnone L, Logan M, Tessier-Lavigne M, Taniguchi M, Puschel AW and Bussolino F: Class 3 semaphorins control vascular morphogenesis by inhibiting integrin function. Nature 424: 391-397, 2003.

48. Bachelder RE, Lipscomb EA, Lin X, Wendt MA, Chadborn NH, Eickholt BJ and Mercurio AM: Competing autocrine pathways involving alternative neuropilin-1 ligands regulate chemotaxis of carcinoma cells. Cancer Res 63: 5230-5233, 2003.

49. Pavelock K, Braas K, Ouafik L, Osol G and May V: Differential expression and regulation of the vascular endothelial growth factor receptors neuropilin-1 and neuropilin-2 in rat uterus. Endocrinology 142: 613-622, 2001.

50. Buhmeida A, Pyrhonen S, Laato M and Collan Y: Prognostic factors in prostate cancer. Diagn Pathol 1: 1-15, 2006.

51. Davies G, Jiang WG and Mason MD: Cell-cell adhesion molecules and signaling intermediates and their role in the invasive potential of prostate cancer cells. J Urol 163: 985-992, 2000.

52. Ivaska J and Heino J: Adhesion receptors and cell invasion: mechanisms of integrin-guided degradation of extracellular matrix. Cell Mol Life Sci 57: 16-24, 2000.

53. Bonaccorsi L, Muratori M, Marchiani S, Forti G and Baldi E: The androgen receptor and prostate cancer invasion. Mol Cell Endocrinol 246: 157-162, 2006.

54. Prifti S, Zourab Y, Koumouridis A, Bohlmann M, Strowitzki T and Rabe T: Role of integrins in invasion of endometrial cancer cell lines. Gynecol Oncol 84: 12-20, 2002.

55. Clezardin P: Recent insights into the role of integrins in cancer metastasis. Cell Mol Life Sci 54: 541-548, 1998.

56. Nagakawa O, Akashi T, Hayakawa Y, Junicho A, Koizumi K, Fujiuchi Y, Furuya Y, Matsuda T, Fuse H and Saiki I: Differential expression of integrin subunits in DU-145/AR prostate cancer cells. Oncol Rep 12: 837-841, 2004.

57. Lochter A, Navre M, Werb Z and Bissell MJ: alpha1 and alpha2 integrins mediate invasive activity of mouse mammary carcinoma cells through regulation of stromelysin-1 expression. Mol Biol Cell 10: 271-282, 1999 .

58. Kubota S, Ito H, Ishibashi $\mathrm{Y}$ and Seyama Y: Anti-alpha3 integrin antibody induces the activated form of matrix metalloprotease-2 (MMP-2) with concomitant stimulation of invasion through matrigel by human rhabdomyosarcoma cells. Int $\mathbf{J}$ Cancer 70: 106-111, 1997.

59. Koike N, Todoroki T, Komano H, Shimokama T, Ban S, Ohno T, Fukao $\mathrm{K}$ and Watanabe $\mathrm{T}$ : Invasive potentials of gastric carcinoma cell lines: role of alpha 2 and alpha 6 integrins in invasion. J Cancer Res Clin Oncol 123: 310-316, 1997.

60. Cress AE, Rabinovitz I, Zhu W and Nagle RB: The alpha 6 beta 1 and alpha 6 beta 4 integrins in human prostate cancer progression. Cancer Metastasis Rev 14: 219-228, 1995.

61. Lang K, Drell TL IV, Lindecke A, Niggemann B, Kaltschmidt C, Zaenker KS and Entschladen F: Induction of a metastatogenic tumor cell type by neurotransmitters and its pharmacological inhibition by established drugs. Int J Cancer 112: 231-238, 2004 
62. Kostenuik PJ, Singh G and Orr FW: Transforming growth factor beta upregulates the integrin-mediated adhesion of human prostatic carcinoma cells to type I collagen. Clin Exp Metastasis 15: 41-52, 1997.

63. Coppolino MG and Dedhar S: Ligand-specific, transient interaction between integrins and calreticulin during cell adhesion to extracellular matrix proteins is dependent upon phosphorylation/dephosphorylation events. Biochem J 340: 41-50, 1999.

64. Skogseth H, Holt RU, Larsson E and Halgunset J: Tyrosine kinase inhibitors alter adhesivity of prostatic cancer cells to extracellular matrix components. APMIS 114: 225-233, 2006.
65. Onishi T, Yamakawa K, Franco OE, Kawamura J, Watanabe M, Shiraishi T and Kitazawa S: Mitogen-activated protein kinase pathway is involved in alpha6 integrin gene expression in androgen-independent prostate cancer cells: role of proximal Sp1 consensus sequence. Biochim Biophys Acta 1538: 218-227, 2001.

66. Rabinovitz I, Nagle RB and Cress AE: Integrin alpha 6 expression in human prostate carcinoma cells is associated with a migratory and invasive phenotype in vitro and in vivo. Clin Exp Metastasis 13: 481-491, 1995.

67. Zhang W, Alt-Holland A, Margulis A, Shamis Y, Fusenig NE, Rodeck U and Garlick JA: E-cadherin loss promotes the initiation of squamous cell carcinoma invasion through modulation of integrin-mediated adhesion. J Cell Sci 119: 283-291, 2006. 